\title{
CFTR Deletion Confers Mitochondrial Dysfunction and Disrupts Lipid Homeostasis in Intestinal Epithelial Cells
}

\author{
Marie L. Kleme ${ }^{1,2}$, Alain Sané ${ }^{1}$, Carole Garofalo ${ }^{1}$, Ernest Seidman ${ }^{3}{ }^{(\mathbb{D}}$, Emmanuelle Brochiero ${ }^{1}$, \\ Yves Berthiaume ${ }^{4}$ and Emile Levy ${ }^{1,2, *}$ \\ 1 Research Centre, CHU Sainte-Justine, 3175 Sainte-Catherine Rd., Montreal, QC H3T 1C5, Canada; \\ dockleme@yahoo.fr (M.L.K.); sanealaintheo@gmail.com (A.S.); \\ carole.garofalo@recherche-ste-justine.qc.ca (C.G.); Emmanuelle.Brochiero@umontreal.ca (E.B.) \\ 2 Department of Nutrition, Faculty of Medicine, Université de Montréal, 2405 Sainte-Catherine Rd., Montreal, \\ QC H3T 1A8, Canada \\ 3 Division of Gastroenterology, Faculty of Medicine, IBD Laboratory, Research Institute, McGill University \\ Health Center, McGill University, Montreal, QC H3G 1A4, Canada; Ernest.Seidman@McGill.ca \\ 4 Montreal Clinical Research Institute, Montreal, QC H2W 1R7, Canada; yves.berthiaume@ircm.qc.ca \\ * Correspondence: emile.levy@recherche-ste-justine.qc.ca; Tel.: +1-(514)-345-7783
}

Received: 29 May 2018; Accepted: 25 June 2018; Published: 27 June 2018

\begin{abstract}
Background: Cystic Fibrosis (CF) is a genetic disease in which the intestine exhibits oxidative and inflammatory markers. As mitochondria are the central source and the main target of reactive oxygen species, we hypothesized that cystic fibrosis transmembrane conductance regulator (CFTR) defect leads to the disruption of cellular lipid homeostasis, which contributes to mitochondrial dysfunction. Methods. Mitochondrial functions and lipid metabolism were investigated in Caco-2/15 cells with CFTR knockout $\left(\mathrm{CFTR}^{-/-}\right.$) engineered by the zinc finger nuclease technique. Experiments were performed under basal conditions and after the addition of the pro-oxidant iron-ascorbate (Fe/Asc) complex. Results. Mitochondria of intestinal cells with $\mathrm{CFTR}^{-/-}$, spontaneously showed an altered redox homeostasis characterised by a significant decrease in the expression of PPAR $\alpha$ and nuclear factor like 2. Consistent with these observations, 8-oxoguanine-DNA glycosylase, responsible for repair of ROS-induced DNA lesion, was weakly expressed in $\mathrm{CFTR}^{-/-}$cells. Moreover, disturbed fatty acid $\beta$-oxidation process was evidenced by the reduced expression of CPT1 and acyl-CoA dehydrogenase long-chain in $\mathrm{CFTR}^{-/-}$cells. The decline of mitochondrial cytochrome $\mathrm{c}$ and B-cell lymphoma 2 expression pointing to magnified apoptosis. Mitochondrial respiration was also affected as demonstrated by the low expression of respiratory oxidative phosphorylation (OXPHOS) complexes and a high adenosine diphosphate/adenosine triphosphate ratio. In contrast, the FAS and ACC enzymes were markedly increased, thereby indicating lipogenesis stimulation. This was associated with an augmented secretion of lipids, lipoproteins and apolipoproteins in CFTR ${ }^{-/-}$ cells. The addition of Fe/Asc worsened while butylated hydroxy toluene partially improved these processes. Conclusions: CFTR silencing results in lipid homeostasis disruption and mitochondrial dysfunction in intestinal epithelial cells. Further investigation is needed to elucidate the mechanisms underlying the marked abnormalities in response to CFTR deletion.
\end{abstract}

Keywords: cystic fibrosis; fatty acid oxidation; OXPHOS; oxidative stress; apoptosis; lipid metabolism; apolipoprotein biogenesis; lipoprotein secretion 


\section{Introduction}

Cystic Fibrosis (CF) is a lethal genetic disease in Caucasians [1]. It is due to mutations in the CFTR gene, which encodes for the cAMP-activated $\mathrm{Cl}^{-}$-and $\mathrm{HCO}_{3}{ }^{-}$-transporting channels expressed in epithelial cells of many organs [2]. This ATP-binding cassette transporter works not only as an essential anion regulator, but it also participates in the fluidity of glandular secretions [2]. In addition to facilitating the mobilization of native anionic substrates, CFTR promotes the transport of glutathione, the first line of cellular antioxidant defense. Glutathione (GSH) is the most important actor in the control of thiol redox status [3] and is involved in free radical scavenging, metal chelation and DNA protection [4]. Many studies reported GSH deficiency in CF in association with intestinal malabsorption of fat and antioxidant lipovitamins, thereby contributing to weak protection against oxidative stress $(\mathrm{OxS})$ in $\mathrm{CF}$. Moreover, OxS in CF may result from endoplasmic reticulum stress, airway chronic neutrophilia and impaired antioxidant defense because of intestinal transport disorders $[5,6]$. In addition, mitochondria in CF exhibit several abnormalities, suggesting an oxidative impairment [7]. Finally, peroxisome proliferator activated receptor gamma coactivator-1-alpha (PGC-1 $\alpha$ ) could be impaired in CF since it represents the key regulator of mitochondria biogenesis, a control protein for the major transcription factors involved in $\beta$-oxidation, Krebs cycle and oxidative phosphorylation [8], and a central modulator of OxS through the enhancement of reactive oxygen species (ROS) detoxification enzyme [9].

OxS and inflammation co-exist in various disorders, and the two processes are recognized as major etiological factors in CF pathophysiology in the lungs and pancreas [10-12]. Although inflammation is triggered by airway chronic infection and essential fatty acid (FA) deficiency (leading to the elevation of pro-inflammatory FA) $[13,14]$, dysfunctional CFTR seems to be directly involved in the activation of macrophage, modulation of cytokine production, and stimulation of nuclear factor kappa B, a powerful transcription factor endowed with the capacity of regulating many genes of innate and adaptive immunity, as well as inflammation [15].

The gastrointestinal tract of CF patients is often characterized by meconium ileus, distal intestinal obstruction, accumulation of viscous and sticky mucus, bacterial overgrowth, ileal hypertrophy and villous atrophy, augmented intestinal permeability, chronic diarrhea, fat malabsorption, reduced secretion of sodium bicarbonate, low duodenal $\mathrm{pH}$, and bile acid precipitation [16]. Despite these severe gastrointestinal manifestations, only a few groups of investigators have focused on the study of the processes of inflammation and OxS in the gut of CF subjects. Our recent study showed that CFTR deletion in intestinal Caco-2/15 cells resulted in a spontaneously weakened antioxidant defense in association with lipid peroxidation and inflammation [17]. In addition, these differentiated cells were more sensitive to pro-oxidant and pro-inflammatory stimuli [6]. Unfortunately, the definitive mechanistic evidence of the link between the primary CF defect and abnormalities in intestinal redox balance and susceptibility to inflammation has yet to be demonstrated. The purpose of the present work is to test the following hypotheses: (i) as oxidant/anti-oxidant imbalance has been observed in the intestine and since mitochondria in various organs are the primary cellular sources and sensitive targets of ROS [18], we surmise that CFTR deletion affects mitochondrial redox homeostasis; (ii) consequently, many mitochondrial functions may be disturbed, including respiration, FA $\beta$-oxidation, energy production and apoptosis; and (iii) conversely, cellular lipid synthesis and transport would be enhanced.

\section{Materials and Methods}

\subsection{CFTR-Knockout in Caco-2/15 Cell Line}

The CFTR deletion in the Caco-2/15 cell line (CFTR $\left.{ }^{-/-}\right)$was generated by the zinc finger nuclease (ZFN) procedure as previously described [17]. Briefly, intestinal Caco-2/15 cells were grown at $37^{\circ} \mathrm{C}$ with $95 \%$ humidity and $5 \% \mathrm{CO}_{2}$ in Eagle's minimum essential medium (EMEM) supplemented with $10 \%$ decomplemented foetal bovine serum, 1\% Penicillin-Streptomycin and 1\% non-essential amino 
acids (NEAA, all reagents from GIBCO- BRL, Grand Island, NY, USA). At 95\% confluence, according to the procedure provided by Sigma-Aldrich (St Louis, MO, USA), the cells were transfected with two ZFN plasmid constructs targeted to human CFTR gene (CKOZFN1722). These ZFNs bind to a specific locus on CFTR sequence and cause a double-strand break that is ultimately repaired in the cell by the process of non-homologous end joining to generate precisely targeted genomic edits resulting in cell lines with specific gene disruption. The integrity of cells was monitored by assessment of villin protein expression whereas differentiation was determined by the measurement of sucrase activity $[19,20]$. The physical barrier function was characterised by transepithelial electric resistance measurement and occludin protein expression [21]. The untransfected intestinal epithelial Caco-2/15 cells served as the control (CTL).

\subsection{Cell Culture}

CTL and $\mathrm{CFTR}^{-/-}$cells were cultured at $37{ }^{\circ} \mathrm{C}$ with $95 \%$ humidity and $5 \% \mathrm{CO}_{2}$, at a density of $5 \times 10^{6} /$ Petri dish containing $10 \mathrm{~mL}$ EMEM supplemented with $1 \%$ penicillin-streptomycin, $1 \%$ NEAA and $5 \%$ decomplemented foetal bovine serum. The culture medium was refreshed every three days, and the cells were used fifteen days post confluence when they were highly differentiated and suitable for experiments.

\subsection{Isolation of Mitochondria}

The mitochondrial fraction was isolated from Caco-2/15 cell monolayers by differential centrifugation according to our previously reported method [7,22-24]. Briefly, after homogenization in sucrose extraction buffer $(0.25 \mathrm{M}, \mathrm{pH} 7.38)$, a light centrifugation $\left(1000 \times g \times 10 \mathrm{~min}\right.$ at $\left.4{ }^{\circ} \mathrm{C}\right)$ was performed to sediment nuclei and cell debris. The resulting supernatant was subsequently centrifuged twice $\left(10,000 \times g \times 10 \mathrm{~min}\right.$ at $\left.4{ }^{\circ} \mathrm{C}\right)$ to separate mitochondria. The crude mitochondrial pellet was then resuspended in sucrose buffer and used for further experiments. The protein content of the mitochondrial suspensions was determined by Bradford assay (BioRad, Mississauga, ON, Canada).

\subsection{Induction of $\mathrm{OxS}$}

Fifteen days post confluence, the CTL and CFTR ${ }^{-/}$cells were washed twice with PBS and incubated in serum-free EMEM supplemented with 1\% penicillin-streptomycin and 1\% NEAA for 18 hours in the presence or absence of the antioxidant butylated hydroxy toluene (BHT, $0.5 \mathrm{mM}$ ) (Sigma-Aldrich, St Louis, MO, USA). At the end of this incubation period (18 h), the medium was removed and cells were cultured with a mixture of $200 \mu \mathrm{M}$ iron (II) sulphate heptahydrate (Sigma-Aldrich, St Louis, MO, USA) and $2 \mathrm{mM}$ ascorbate (Sigma-Aldrich, St Louis, MO, USA) for $6 \mathrm{~h}$ at $37^{\circ} \mathrm{C}$ to induce OxS. This strong oxygen radical-generating system was employed to challenge cells and to evaluate their capacity to respond to an external pro-oxidant stimulus.

\subsection{Protein Expression Analysis by Immunoblotting}

Protein samples $(30 \mu \mathrm{g})$ were denatured for $10 \mathrm{~min}$ in a buffer containing SDS and mercaptoethanol. They were separated on a 12\% SDS-polyacrylamide gel according to protein molecular weights and were electroblotted onto nitrocellulose or PVDF membranes. Defatted milk proteins were used to block nonspecific sites of the membranes before adding primary antibodies: rabbit polyclonal anti-peroxisome proliferator activated receptor gamma coactivator-1-alpha (PGC-1 $\alpha, 100 \mathrm{kDa}, 1: 1000$, Abcam, Cambridge, MA, USA); rabbit anti- nuclear factor (erythroid-derived 2)-like 2 (Nrf-2, $68 \mathrm{kDa}$, 1:1000, Abcam, Cambridge, MA, USA); rabbit polyclonal anti-8-oxoguanine-DNA glycosylase (OGG1, $39 \mathrm{kDa}, 1: 1000$, Novus biologicals, Oakville, ON, Canada); mouse anti-cytochrome c (15 kDa, 1:1000, Novus biologicals, Oakville, ON, Canada); rabbit polyclonal anti-Bcl-2 (25 kDa, 1:1000, Abcam Cambridge, MA, USA); rabbit monoclonal anti-carnitine palmitoyltransferase-1 A (CPT1A, $88 \mathrm{kDa}, 1: 1000$, Cell Signaling, Beverly, MA, USA), rabbit polyclonal anti-Acyl-CoA dehydrogenase long-chain (ACADL, 45 kDa, 1:1000, ThermoFisher scientific, Burlington, ON, Canada); Total OXPHOS 
Human WB antibody cocktail (CV 54 kDa, CIII 48 kDa, CII 29 kDa, CIV 22 kDa, CI 18 kDa, 1:250, Abcam Cambridge, MA, USA); mouse anti- $\beta$-actin (42 kDa, 1:250,000, Sigma-Aldrich, St Louis, MO, USA); rabbit monoclonal anti-fatty acid synthase (FAS, $273 \mathrm{kDa}, 1: 1000$, Cell Signaling, Beverly, MA, USA); rabbit anti-Acetyl CoA carboxylase (ACC, $280 \mathrm{kDa}, 1: 1000$, Cell signaling, Beverly, MA, USA) . The relative amount of primary antibody was detected with species-specific horseradish peroxidase-conjugated secondary antibody (Jackson Laboratory, Bar Harbor, ME, USA). Expression of $\beta$-actin served as a reference protein to confirm equal loading. Molecular size markers (BLUeye/PageRuler prestained protein ladder, ThermoFisher scientific, Burlington, ON, Canada) were concomitantly loaded on gels. Blots were developed and the protein mass was quantitated using an HP Scanjet scanner equipped with a transparency adapter and the UNSCAN-IT gel 6.1 software (Silk Scientific, Orem, UT, USA). Importantly, even if identical protein amounts of tissue homogenates were applied, the $\beta$-actin protein was used to confirm equal loading on SDS-PAGE. Its expression was evidenced after stripping the blot and re-probing with its specific antibody.

\subsection{RNA Isolation and RT-PCR}

Total RNA was extracted from differentiated CTL and $\mathrm{CFTR}^{-/-}$Caco-2/15 cells using QIAzol lysis reagent (Invitrogen, Thermo Fisher scientific, Burlington, ON, Canada) and reverse transcribed to generate cDNA. This was amplified by PCR using Taq polymerase (Feldan Bio, Quebec, QC, Canada) according to the manufacturer's instructions. GAPDH (as internal control) and CFTR as described previously [17].

\subsection{Fatty Acid $\beta$-Oxidation}

Cells were rinsed twice with PBS (Gibco, Thermo Fisher scientific, Burlington, ON, Canada) before being pre-incubated with serum-free EMEM for $1 \mathrm{~h}$ in flasks fitted with central wells, suspended through an air-tight rubber bung. Cells were supplemented with a solution containing $0.90 \mu \mathrm{Ci}$ U-( $\left(\mathrm{C}^{14}\right)$-palmitic acid (Perkin Elmer, $\left.850 \mathrm{mCi} / \mathrm{mmol}\right), 250 \mu \mathrm{M}$ unlabeled palmitic acid (Sigma-Aldrich, St Louis, MO, USA) and $2 \mathrm{~mL}$ serum-free EMEM and $10 \mu \mathrm{L} / \mathrm{mL}$ of each anti-protease (PMSF, Leupeptin and Pepstatin) for $18 \mathrm{~h}$ while $\mathrm{NaOH}$ was added to each central well to trap released $\left({ }^{14} \mathrm{C}\right)-\mathrm{CO}_{2}$, and $\left({ }^{14} \mathrm{C}\right)$-oxidized to $\left({ }^{14} \mathrm{C}\right)-\mathrm{CO}_{2}$ was measured as described previously [25]. Briefly, $\left({ }^{14} \mathrm{C}\right)-\mathrm{CO}_{2}$ was driven from medium by adding $300 \mu \mathrm{L}$ of $0.7 \mathrm{~N}$ hydrochloric acid and trapped in the central well saturated with $10 \times$ hyamine hydroxide. Flasks were shaken for a further 45 -min period at room temperature to increase trapping of $\left({ }^{14} \mathrm{C}\right)-\mathrm{CO}_{2}$, after which the center wells were placed in plastic vials, dark-adapted overnight, and assayed for radioactivity in a liquid scintillation counter.

\subsection{Measurement of Mitochondrial ADP/ATP Ratio}

The adenosine diphosphate/adenosine triphosphate (ADP/ATP) ratio was measured by bioluminescence assay using the Enzlight ${ }^{\mathrm{TM}}$ ADP / ATP ratio assay kit (ELDT-100) (BioAssay Systems, Hayward, CA, USA) as described previously [7,22-24]. Results were normalized according to the protein content of the mitochondria.

\subsection{Lipid and Lipoprotein Assessment}

Specifically, for these experiments, cells were seeded at a density of $1 \times 10^{6} /$ well in six-well polycarbonate Transwell filter inserts plates (Costar Cambridge, MA, USA) containing $2.5 \mathrm{~mL}$ of culture medium in the basolateral compartment and $15 \mathrm{~mL}$ in the apical one. The culture medium was refreshed every 3 days. Fifteen days after seeding, cells were washed twice with PBS and supplied with $2.5 \mathrm{~mL}$ serum-free EMEM in the basolateral chamber and $1.5 \mathrm{~mL}$ serum-free EMEM containing (BSA/oleic acid) (1:5, mol:mol, pH 7.4) in the apical chamber. BHT (0.5 mM) was added to serve as an antioxidant when needed. After $18 \mathrm{~h}$, the culture medium was discarded and replaced with fresh $2.5 \mathrm{~mL}$ serum-free EMEM and $1.5 \mathrm{~mL}$ radiolabeled $\left({ }^{14} \mathrm{C}\right)$ oleic acid $(0.45 \mu \mathrm{Ci})(53 \mathrm{mCi} / \mathrm{mmol}$; Amersham, Oakville, ON, Canada) in the basolateral and the apical compartments, respectively. 
Fe/Asc $(200 \mu \mathrm{M} / 2 \mathrm{mM})$ with or without BHT $(0.5 \mathrm{mM})$ was added apically. After a 24 h-incubation, media were collected from the two chambers and cells were washed twice with cold PBS and scraped in $1 \mathrm{~mL}$ of lysis buffer $(1 \times$ TBS, pH 7.4; 5 mM EDTA; 0.1\% SDS; $1 \%$ Triton $\times 100 ; 0.5 \%$ Sodium deoxycholate) containing $10 \mu \mathrm{L} / \mathrm{mL}$ of each anti-protease (PMSF, Leupeptin and Pepstatin).

\subsection{Lipid Extraction}

Lipids were extracted from the basolateral medium with chloroform/methanol (v/v, 2:1). After overnight shaking at $4{ }^{\circ} \mathrm{C}$, saline was added and the samples were centrifuged (2500 rpm for $15 \mathrm{~min}$ ). Then, the lower phase was evaporated. The esterified lipids from the precursor $\left({ }^{14} \mathrm{C}\right)$-oleic acid were separated by TLC plates using the solvent mixture hexane-ether-acetic acid $(80: 20: 3, v / v / v)$. The area of triglycerides (TG), cholesteryl esters (CE) and phospholipids (PL) was scratched off the TLC plates and radioactivity contained in the silica powder was counted by scintillation counting (Beckman Coulter, Fullerton, CA, USA), using the scintillation liquid EcoLite (MP Biomedicals, ThermoFisher scientific, Burlington, ON, Canada). Results were expressed as dpm per milligram of cell protein, quantified by the Bradford method [26-28].

\subsection{Lipid Carrier}

Blood was drawn $3 \mathrm{~h}$ after the ingestion of a high-fat meal by a human volunteer. It was centrifuged to remove red blood cells, and the postprandial plasma supplemented with $1 \mathrm{mM}$ of aprotinin and $0.1 \%$ of sodium azide served as a carrier for the synthesis of TG-rich lipoproteins as described previously [29].

\subsection{Isolation of Lipoproteins}

Newly synthesized lipoproteins were separated from the basolateral medium supplemented with anti-proteases and to which plasma lipid carrier was added $(4: 1, v / v)$ to efficiently isolate de novo produced lipoproteins. Isolation was performed by sequential ultracentrifugation using a TL-100 ultracentrifuge as per our usual technique [30-32]. Briefly, chylomicrons (CM)s were isolated after ultracentrifugation (25,000 rpm for $40 \mathrm{~min}$ ). The lower phase was used to isolate successively very low-density lipoprotein (VLDL; $1.006 \mathrm{~g} / \mathrm{mL})$ and LDL $(1.063 \mathrm{~g} / \mathrm{mL})$ at 100,000 rpm for $2.30 \mathrm{~h}$ with a tabletop ultracentrifuge 100.4 rotor at $4{ }^{\circ} \mathrm{C}$. Then, the density of LDL infranatant was adjusted to $1.21 \mathrm{~g} / \mathrm{mL}$ before centrifuging at 100,000 rpm for $6.5 \mathrm{~h}$ to efficiently isolate HDL. Each lipoprotein fraction was exhaustively dialyzed at $4{ }^{\circ} \mathrm{C}$ for $24 \mathrm{~h}$ into a solution contained $0.15 \mathrm{M} \mathrm{NaCl}$ and $0.001 \mathrm{M}$ EDTA. The radioactivity incorporated into each lipoprotein was then assessed and reported as disintegrations per minute per milligram of cellular protein.

\subsection{De Novo Apolipoproteins Synthesis}

The synthesis and secretion of apolipoproteins (apos) were determined as described previously [33]. Briefly, Caco-2/15 cells were incubated for a period of $24 \mathrm{~h}$ with $67 \mu \mathrm{Ci} / \mathrm{mL}$ of $\left({ }^{35} \mathrm{~S}\right)$-methionine in serum and methionine-free DMEM (Gibco, ThermoFisher scientific, Burlington, ON, Canada) containing NEAA and puromycin $(2 \mu \mathrm{g} / \mathrm{mL})$. After the incubation period, cells and basolateral medium were collected and antiproteases were added at a concentration of $1 \mathrm{mM}$. Cells were homogenized in the same lysis buffer as above. Excess amounts of antibodies against apos were added to cells along with A/G protein beads (Calbiochem, La Jolla, CA, USA) and incubated overnight at $4{ }^{\circ} \mathrm{C}$. The immunoprecipitates were washed extensively with lysis buffer and analyzed on a $4-15 \%$ acrylamide gradient with a 3\% stacking gel. Bands corresponding to all apos were excised off the gel and counted after an overnight incubation with $1 \mathrm{~mL}$ of BTS-450 (Beckman Coulter, Fullerton, CA, USA) and a 48-h incubation in $10 \mathrm{~mL}$ of liquid scintillation fluid (Ready Organic, Beckman Coulter, Fullerton, CA, USA). Results are reported as the ratio of disintegrations per minute of apos per milligram of protein. 


\subsection{Statistical Analysis}

All values are expressed as the mean \pm standard error of the mean (SEM) of at least 3 different experiments carried out in triplicate. Data were analyzed by the two-tailed Student's t test or one-way ANOVA using PRISM 6.0 (GraphPad Software). Differences were considered significant at $p<0.05$.

\section{Results}

Before initiating the series of planned experiments, we validated the effectiveness of ZFN to generate total CFTR suppression in Caco-2/15 cells. qPCR and western blot confirmed the full deletion of CFTR gene and protein expression, respectively [17] (Figure 1). Appropriate precautions have been taken to ensure that the cell integrity was preserved following genetic manipulation. Confirmation was obtained by testing trypan blue exclusion, transepithelial resistance, sucrase activity, villin protein expression and occludin protein expression (Table 1).
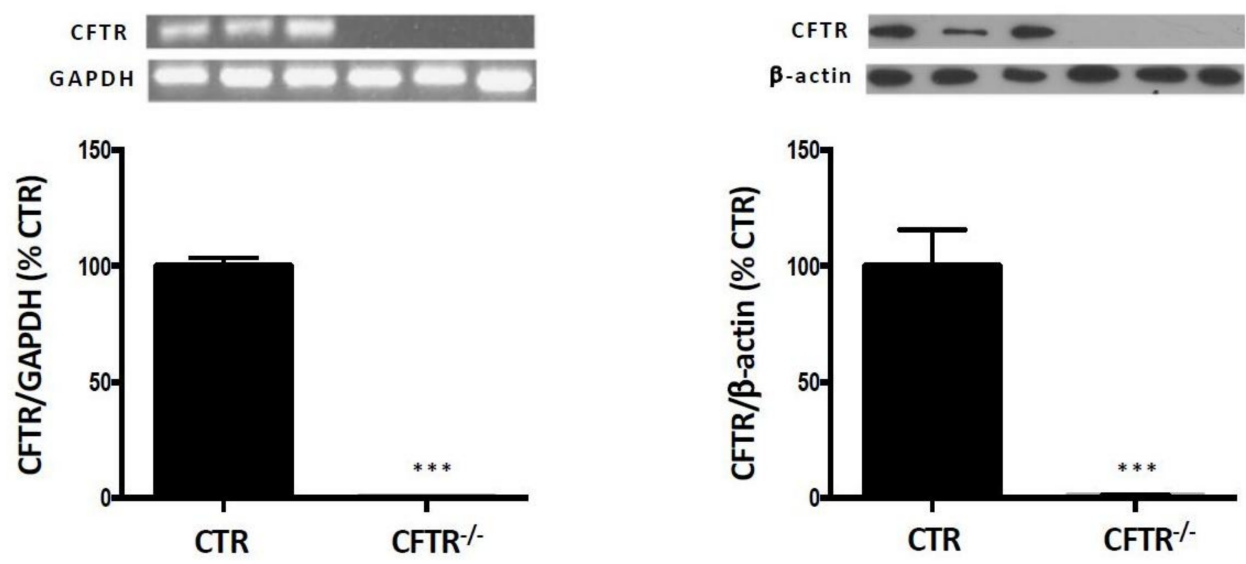

Figure 1. CFTR gene and protein expression in control and CFTR ${ }^{-/-}$Caco- $2 / 15$ cells. Knockout of the CFTR gene by the ZFN technology resulted in full deletion of mRNA and protein expression, which were assessed by RT-PCR and Western blot, respectively. The CFTR ${ }^{-/-}$cell line is thus appropriate to mimic the homozygous CF phenotype. Values are means \pm standard error of the mean (SEM) of 3 independent experiments. ${ }^{* * *} p<0.001$ vs. CTR cells. CTR: control cells; ZFN: zinc finger nuclease.

Table 1. CFTR knockout and Caco-2/15 cell integrity.

\begin{tabular}{ccc}
\hline VIABILITY CRITERIA & Control Cells & CFTR $^{-/-}$Cells \\
\hline Trypan blue exclusion & $>96 \%$ & $>96 \%$ \\
Transepithelial resistance $\left(\Omega \times \mathrm{cm}^{2}\right)$ & $100 \pm 20$ & $96 \pm 14$ \\
Sucrase activity (UI/g proteins) & $100 \pm 21$ & $94 \pm 15$ \\
Villin protein expression (\% of controls) & $100 \pm 11$ & $102 \pm 11$ \\
Occludin protein expression (\% of controls) & $100 \pm 6$ & $105 \pm 5$
\end{tabular}

Following CFTR silencing by the ZFN technique, Caco-2/15 cells were allowed to differentiate for 15 days. The cellular integrity was assessed using trypan blue exclusion (as a viability marker) and also by the determination of transepithelial resistance and occludin (as indicators of cell permeability and epithelial barrier function, respectively), as well as the expression of sucrase activity and villin protein mass (as markers of cell differentiation). Values are means \pm standard error of the mean (SEM) of 3 independent experiments, each performed in triplicate.

\subsection{Mitochondrial Antioxidant Defense}

Since our previous studies demonstrated that the absence of functional CFTR in Caco-2/15 cells promoted exaggerated pro-oxidative response [17], we evaluated the antioxidant status in mitochondria, which are considered as the central source of ROS in different organs [18]. Assessment of mitochondrial $\mathrm{H}_{2} \mathrm{O}_{2}$ showed increased levels in $\mathrm{CFTR}^{-/-}$compared to CTL cells (Figure 2A). Conversely, there was a significant decrease in the protein expression of $\mathrm{Nrf2}$, a critical transcription factor that 
upregulates the expression of many antioxidant genes (Figure 2B). In addition, CFTR ${ }^{-/-}$Caco-2/15 cells exhibited a marked decline in the protein expression of mitochondrial OGG1, responsible for repair of ROS-induced DNA lesions in humans, [34] (Figure 2C) and in PGC-1 $\alpha$, the master mitochondrial biogenesis regulator and ROS suppressor [8,35] (Figure 2D). These results highlight the link between CFTR ablation and mitochondrial pro-oxidant/oxidant imbalance under basal conditions. The addition of Fe/Asc led to a further decrease of these values and the pre-incubation with BHT improved the level of Nrf2 but not PGC-1 $\alpha$, assessed in cell homogenates (Figure 2).
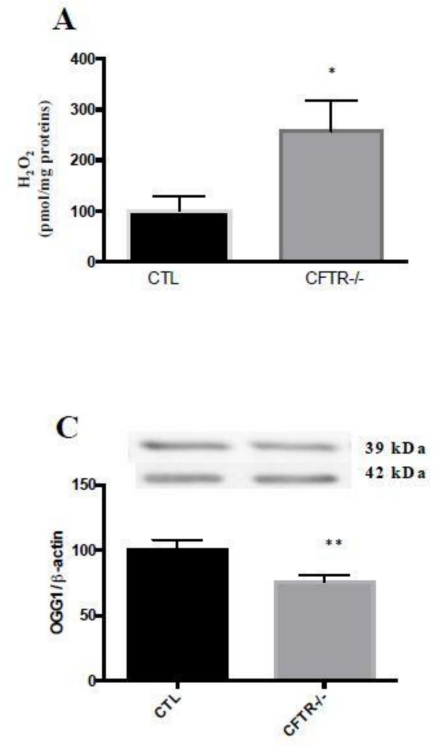

B

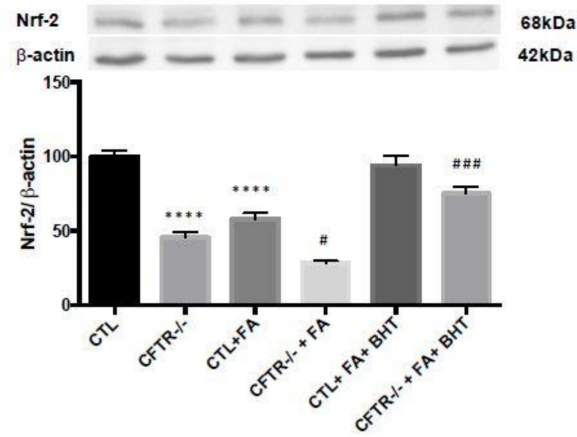

D

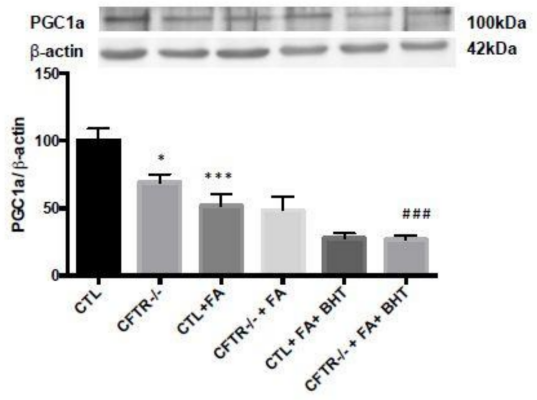

Figure 2. Impact of CFTR deletion on mitochondrial pro-oxidant and antioxidant defense in control and $\mathrm{CFTR}^{-/-}$cells. After cellular differentiation, Caco-2/15 cells were harvested, trypsinized and homogenized. (A) Mitochondrial $\mathrm{H}_{2} \mathrm{O}_{2}$ was measured by a bioluminescence assay whereas Western blot served to estimate the protein mass of (B) nuclear factor (erythroid-derived 2)-like2 (Nrf2) in homogenate, (C) 8-oxoguanine DNA glycosylase (OGG1) in mitochondria, and (D) peroxisome proliferator activated receptor gamma coactivator-1-alpha $(\mathrm{PGC}-1 \alpha)$ in homogenate. Values are means \pm SEM of $3-5$ independent experiments, each done in triplicate. ${ }^{*} p<0.05,{ }^{* *} p<0.01,{ }^{* * *} p<0.001,{ }^{* * * *} p<0.0001$ vs. CTL cells; \# $p<0.05$, \#\#\# $p<0.001$ vs. CFTR $^{-/-}$cells. CTR: control cells; FA: iron/ascorbate (200 $\mu \mathrm{M} / 0.5 \mathrm{mM})$; BHT: Butylated hydroxy toluene $(0.5 \mathrm{mM})$.

\subsection{Fatty Acid $\beta$-Oxidation}

To test the impact of CFTR deletion on mitochondrial oxidative capacity, we incubated intestinal cells with (U-14 $\mathrm{C})$-palmitic acid and, at the end of the incubation period, $\left({ }^{14} \mathrm{C}\right)-\mathrm{CO}_{2}$ production was estimated. As illustrated in Figure 3A, the catabolism of the labeled palmitate was significantly decreased $(36 \%, p<0.05)$ in CFTR $^{-/-}$Caco-2/15 cells. Similarly, the CFTR deletion reduced $\left(\mathrm{U}-{ }^{14} \mathrm{C}\right)$-palmitate oxidation into $\left({ }^{14} \mathrm{C}\right)$-acid-soluble products $(22 \%, p<0.05)$ (Figure $\left.3 \mathrm{~B}\right)$. In addition, cell treatment with $\mathrm{Fe} / \mathrm{Asc}$ further reduced the FA $\beta$-oxidation while the pre-incubation with BHT attenuated Fe/Asc-induced metabolite fall and to a lesser degree in $\mathrm{CFTR}^{-/}$cells (Figure 3A).

These results prompted us to appraise the mitochondrial expression of CPT1 and ACADL since these proteins are rate-controlling enzymes of the FA $\beta$-oxidation pathway. Our results demonstrated that under basal conditions, CPT1A expression was lower in CFTR $^{-/-}(43 \%, p<0.01)$ than in CTL cells (Figure 3C). When Fe/Asc was added, the expression was further depressed while BHT did not significantly restore CPT1A protein expression in both CTL and CFTR ${ }^{-/-}$cells. (Figure 3C). Without any treatment, the protein expression of ACADL in CFTR ${ }^{-/-}$cells significantly declined $(28 \%, p<0.01)$ 
compared to CTL cells (Figure 3D). Under pro-oxidant conditions triggered by Fe/Asc, ACADL protein mass was even significantly depressed and BHT failed to re-establish it (Figure 3D).

A

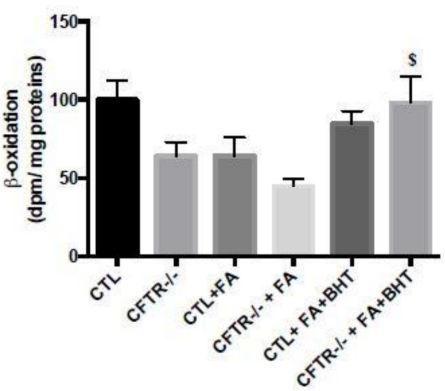

C
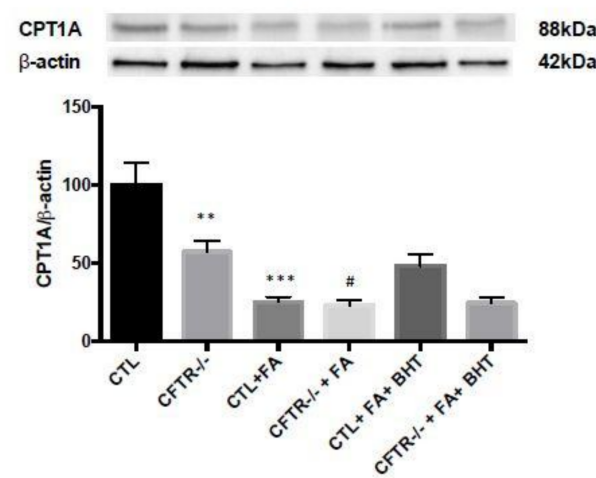

B

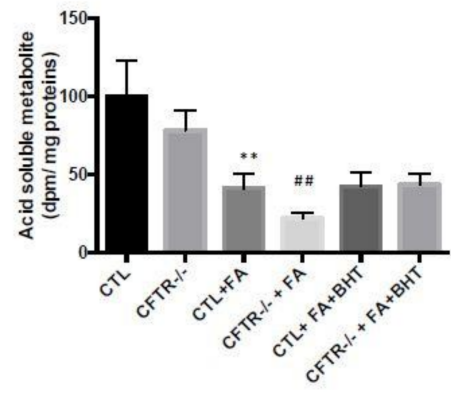

D
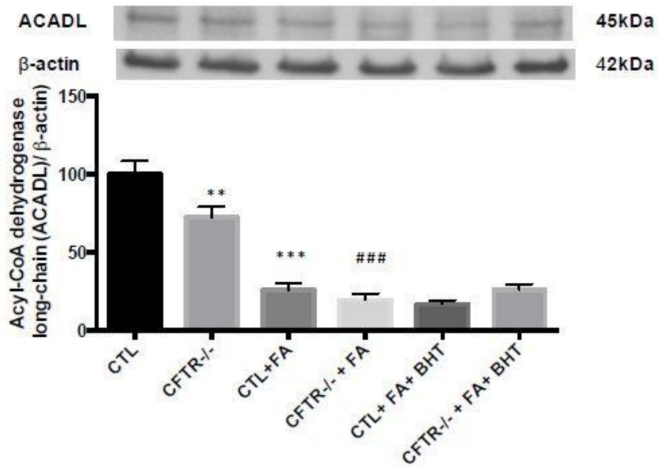

Figure 3. Influence of CFTR suppression on mitochondrial fatty acid $\beta$-oxidation and related regulatory enzymes. At the end of 15 days of differentiation, Caco- $2 / 15$ cells were harvested, trypsinized and resuspended. Thereafter, cells were incubated with palmitate. $\beta$-oxidation was monitored by quantification of $(\mathrm{A})\left({ }^{14} \mathrm{C}\right)$-palmitate oxidized to $\left({ }^{14} \mathrm{C}\right)-\mathrm{CO}_{2}$ and $\left({ }^{14} \mathrm{C}\right)$-acid-soluble products. (B) Complex II (CII). Mitochondrial protein mass of (C) carnitine palmitoyl transferase 1 A (CPT1A) and (D) acyl-coA dehydrogenase long chain (ACADL) was analyzed by western blotting. Values are means \pm SEM of 3 independent experiments, each performed in triplicate. ${ }^{* *} p<0.01$, ${ }^{* *} p<0.001$ vs. CTL cells; $\# p<0.05, \# \# p<0.01$, \#\# $p<0.001$ vs. CFTR $/-$ cells; $\$ p<0.05$ vs. CFTR ${ }^{-/-}+$FA cells. CTR: control cells; FA: iron/ascorbate (200 $\mu \mathrm{M} / 0.5 \mathrm{mM})$; BHT: Butylated hydroxy toluene $(0.5 \mathrm{mM})$.

\subsection{Oxidative Phosphorylation}

To determine whether the suppression of CFTR affects oxidative phosphorylation (OXPHOS), a central metabolic pathway in mitochondria, the respiratory chain complexes were evaluated. Their mitochondrial protein expression, examined by immunoblotting, revealed a significant decrease

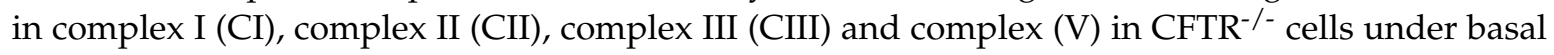
conditions (Figure 4A-C,E). Complex IV (CIV) protein expression was only slightly reduced (Figure 4D). When Fe/Asc was added, the protein expression of all the complexes was further decreased particularly in $\mathrm{CFTR}^{-/-}$cells compared to CTL cells (Figure 4). Pre-incubation of cells with BHT failed to normalize mitochondria respiratory chain complexes expression in both CFTR ${ }^{-/-}$and CTL cells (Figure 4).

\subsection{ADP/ATP Ratio}

As the major biological function of mitochondria consists in generating cellular energy through FA $\beta$-oxidation and oxidative phosphorylation, we measured mitochondrial ADP/ATP ratio. The results showed that $\mathrm{CFTR}^{-/-}$cells spontaneously exhibited a significant elevation $(185 \%, p<0.05)$ in ADP / ATP ratio compared to CTL cells (Figure 5). 
A

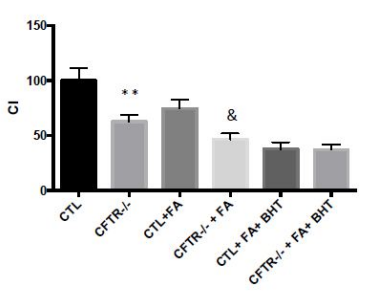

B

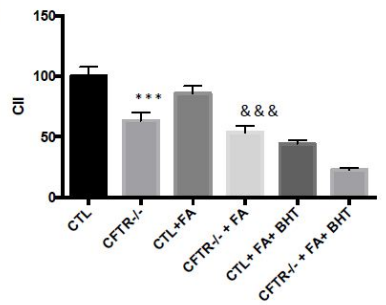

C

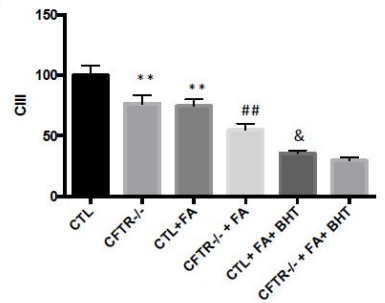

D

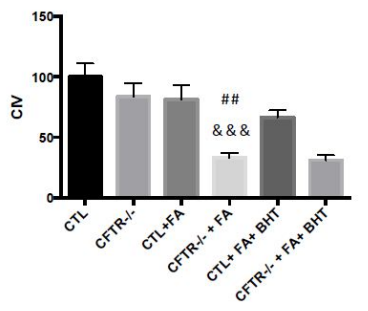

E

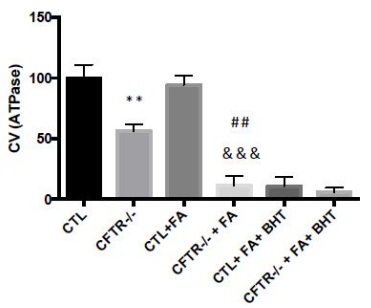

Figure 4. Effect of CFTR abrogation on mitochondrial oxidative phosphorylation. After 15 days differentiation, Caco-2/15 cells were trypsinized and mitochondria were isolated by ultracentrifugation to assess the protein mass by western blotting of (A) respiratory chain complex I (CI); (B) complex II (CII); (C) complex III (CIII); (D) complex IV (CIV); and (E) complex V (CV). Values are means \pm SEM of 5 independent experiments, each performed in triplicate. ${ }^{* *} p<0.01,{ }^{* * *} p<0.001$ vs. CTL cells; \#\# $p<0.01$ vs. CFTR ${ }^{-/-}$cells; $\& p<0.05, \& \& \& p<0.001$ vs. CTL + FA cells. CTR: control cells; FA: iron/ascorbate $(200 \mu \mathrm{M} / 0.5 \mathrm{mM})$; BHT: Butylated hydroxy toluene $(0.5 \mathrm{mM})$.

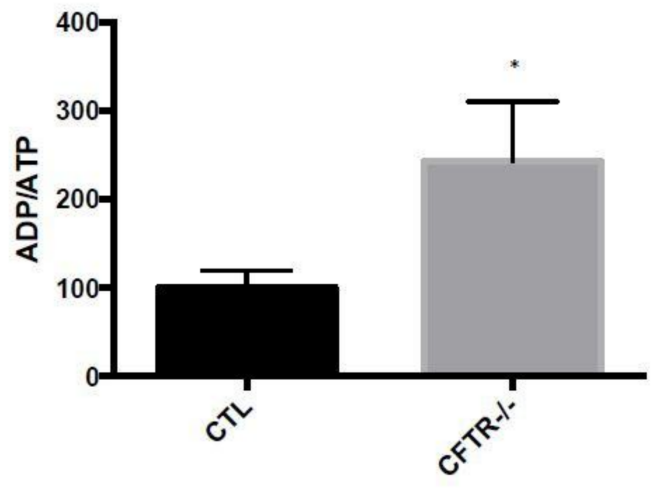

Figure 5. Effects of CFTR deletion on mitochondrial ADP/ATP ratio. Caco-2/15 cells were allowed to differentiate until 15 days after confluence. Then, cells were, harvested, trypsinized and homogenized. The ADP / ATP ratio was measured in isolated mitochondria by a bioluminescence assay. Values are means \pm SEM of 3 independent experiments, each performed in triplicate. ${ }^{*} p<0.05$ vs. CTR cells. CTR: control cells; FA: iron/ascorbate $(200 \mu \mathrm{M} / 0.5 \mathrm{mM})$; BHT: Butylated hydroxy toluene $(0.5 \mathrm{mM})$.

\subsection{Apoptosis-Related Proteins}

Mitochondrial cytochrome $\mathrm{c}$ and $\mathrm{Bcl}-2$ proteins usually serve to explore apoptosis. Our experiments demonstrated that, under basal conditions, the protein expression of cytochrome c $(14 \%, p<0.01)$ (Figure $6 \mathrm{~A}$ ) and $\mathrm{Bcl} 2(77 \%, p<0.01)$ (Figure $6 \mathrm{~B})$ in the mitochondria of $\mathrm{CFTR}^{-/-}$cells was significantly lower than that in CTL cells. Fe/Asc administration led to deep decreases in Bcl2 protein expression particularly in $\mathrm{CFTR}^{-/-}$cells $(19.9 \%, p<0.0001)$ (Figure $\left.6 \mathrm{~B}\right)$ and cytochrome c protein expression 
remained low $(12 \%, p<0.01)$ (Figure $6 \mathrm{~A})$. Pre-incubation of cells with BHT significantly restored mitochondrial expression of especially cytochrome c in CTL cells (83\%). (Figure 6).

A

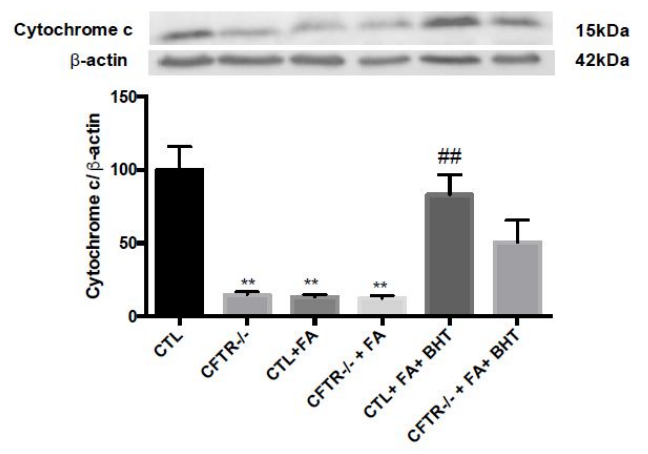

B

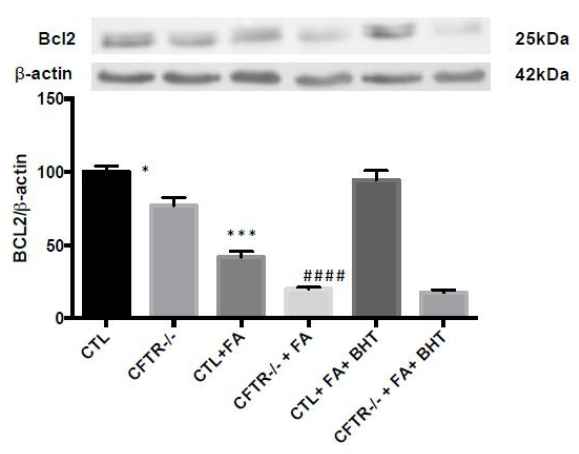

Figure 6. Impact of CFTR depletion on mitochondrial apoptosis-related proteins. Mitochondria were isolated from differentiated Caco-2/15 cells by ultracentrifugation. Then, protein mass of (A) cytochrome c and (B) B-cell lymphoma $2(\mathrm{Bcl} 2)$ was quantified by western blotting. Values are means \pm SEM of 3 independent experiments, each performed in triplicate. ${ }^{*} p<0.05,{ }^{* *} p<0.01,{ }^{* * *} p<0.001$ vs. CTL cells; \#\# $p<0.01$, \#\#\# $p<0.0001$ vs. CFTR ${ }^{-/-}$cells. CTR: control cells; FA: iron/ascorbate (200 $\mu \mathrm{M} / 0.5 \mathrm{mM})$; BHT: Butylated hydroxy toluene $(0.5 \mathrm{mM})$.

\subsection{Lipogenesis}

As opposite regulation characterizes FA $\beta$-oxidation and the lipogenesis pathway, we examined the protein expression of lipogenic enzymes in total homogenates to test whether they were up-regulated in contrast with the down-regulated enzymes reported above in the FA catabolic process. Indeed, the results revealed that, under basal conditions, FAS $(165 \%, p<0.01)$ and ACC $(194 \%$, $p<0.05$ ) protein expression was significantly increased in CFTR ${ }^{-/-}$compared to CTL cells (Figure 7A,B). Comparable differences between $\mathrm{CFTR}^{-/-}$and CTL cells were also noted in FAS and ACC in the presence of Fe/Asc. The addition of BHT was without marked effect on Fe/Asc-induced levels (Figure 7A,B).

\subsection{Lipid Synthesis}

In a second step, we challenged CTL and $\mathrm{CFTR}^{-/-}$cells with oleic acid in order to evaluate their ability to synthesize lipids and lipoproteins in Caco-2/15 cells granting access to both sides of the bipolar intestinal epithelium. The results demonstrated that under basal conditions, the $\mathrm{CFTR}^{-/-}$cells significantly raised the output of TG $(644 \%, p<0.0001)$ (Figure 7C), CE $(108 \%, p<0.05)$ (Figure 7D) and PL $(53 \%, p<0.01)$ (Figure 7E) in the basolateral medium. The addition of Fe/Asc led to a drop of lipid secretion in the two cell types. However, the export of lipids to the basolateral medium remained higher in $\mathrm{CFTR}^{-/-}$cells ( $\sim 5$ fold of CTL values). On the other hand, BHT decreased lipid secretion, especially triglycerides, in CFTR ${ }^{-/-}$and CTL cells (Figure 7C).

\subsection{Lipoprotein Production}

As intestinal lipids are transported by lipoproteins, we investigated the impact of CFTR deletion on lipoprotein production. In accordance with the elevated levels, under basal conditions, $\mathrm{CFTR}^{-/-}$ cells were characterized by increased concentrations of chylomicrons $(201 \%, p<0.0001)$ (Figure 8A), VLDL $(610 \%, p<0.0001)$ (Figure 8B), LDL $(421 \%, p<0.0001)$ (Figure 8C) and HDL $(47 \%, p<0.01)$ (Figure 8D) compared to CTR cells. The addition of Fe/Asc resulted in a slightly reduced secretion of lipoproteins while BHT further decreased their production (Figure 8). 

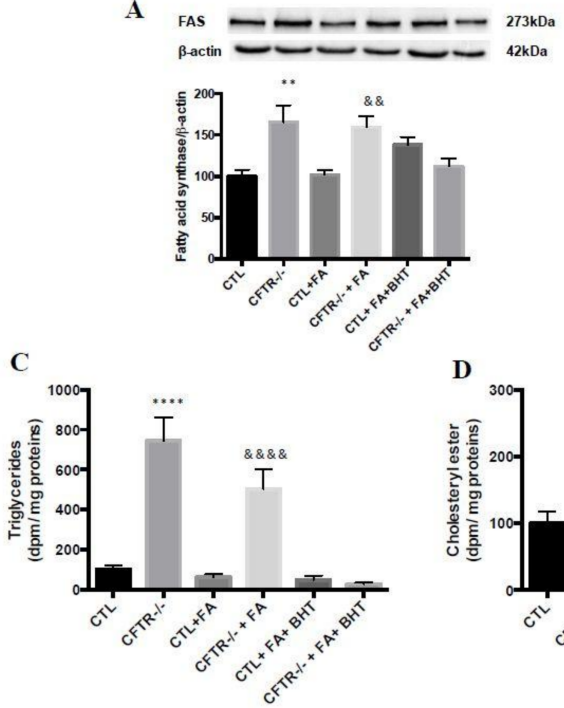

。

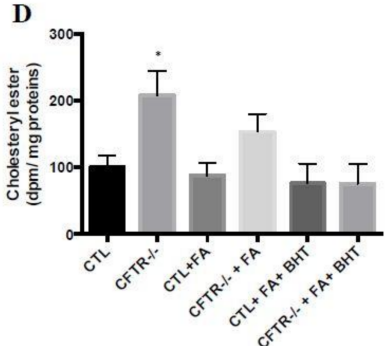

B

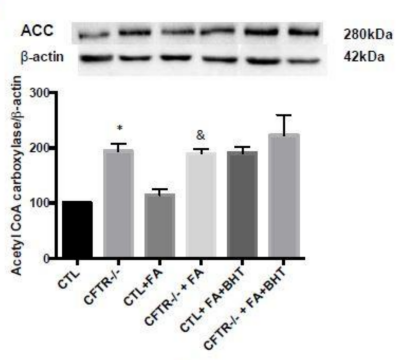

Figure 7. Influence of CFTR deletion on lipogenic enzymes and lipid synthesis. At the end of 15 days of differentiation, Caco-2/15 cells were harvested, trypsinized, and homogenized. Protein mass of (A) fatty acid synthase (FAS) and (B) acetyl CoA carboxylase (ACC) was analyzed by western blotting. Following a challenge cells with $\left({ }^{14} \mathrm{C}\right)$-oleic acid, lipid synthesis was assessed by quantification of (C) triglycerides, (D) cholesteryl ester and (E) phospholipids in basolateral medium. Values are means \pm SEM of 3 independent experiments, each performed in triplicate. ${ }^{*} p<0.05,{ }^{* *} p<0.01$, $* * * * p<0.0001$ vs. CTL cells; \& $p<0.05, \& \& p<0.01, \& \& \& \& p<0.0001$ vs. CTL + FA cells. CTR: control cells; FA: iron/ascorbate $(200 \mu \mathrm{M} / 0.5 \mathrm{mM})$; BHT: Butylated hydroxy toluene $(0.5 \mathrm{mM})$.
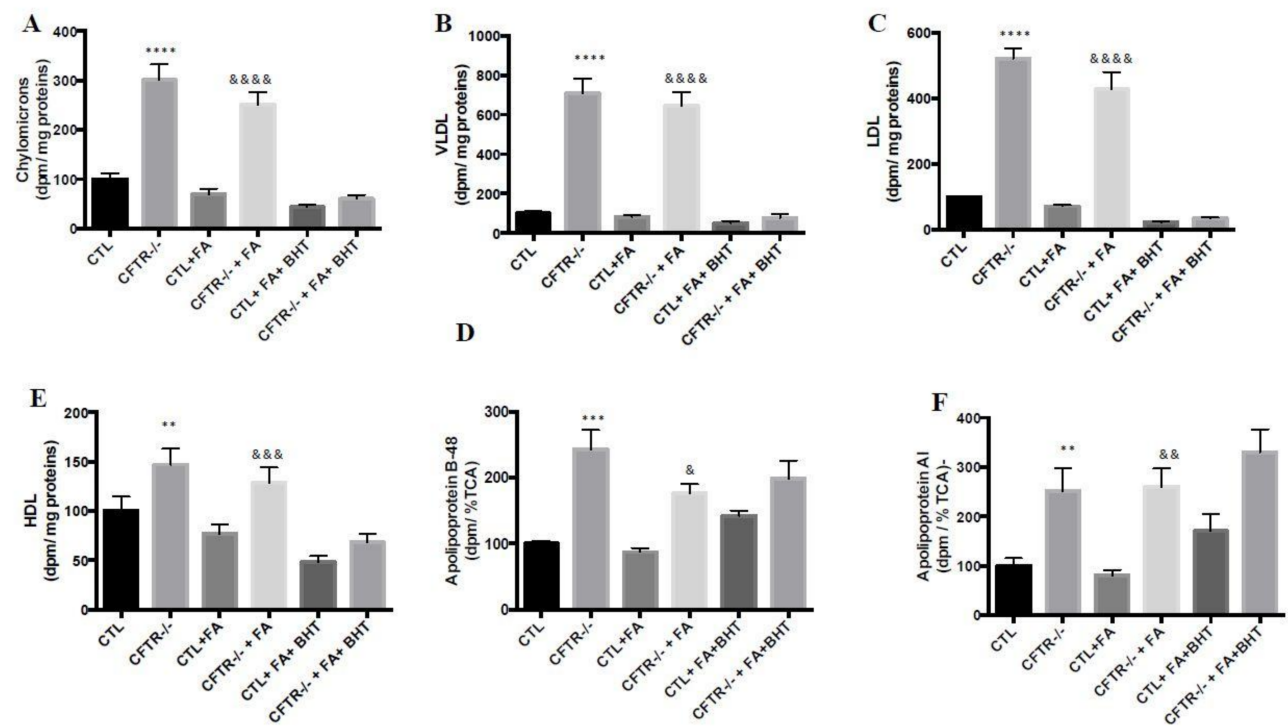

Figure 8. Influence of CFTR deletion on lipoprotein production and on de novo apolipoprotein synthesis in Caco-2/15 cells. Caco-2/15 cells were allowed to differentiate until 15 days after confluence. Then, cells were challenged with $\left({ }^{14} \mathrm{C}\right)$-oleic acid. Lipoproteins production was assessed by quantification of (A) chylomicrons, (B) very low-density lipoproteins, (C) low-density lipoproteins, and (D) high-density lipoproteins in basolateral medium. Caco-2/15 cells were challenged with $\left({ }^{35} \mathrm{~S}\right)$-methionine and de novo apolipoproteins (apo) synthesis was assessed in cell lysate by the measurement of apos (E) B-48 and (F) A-I. Values are means \pm SEM of 3 independent experiments, each performed in triplicate. ${ }^{* *} p<0.01$, ${ }^{* * *} p<0.001,{ }^{* * * *} p<0.0001$ vs. CTL cells; \& $p<0.05$, \&\& $p<0.01$, \&\&\& $p<0.001$, \&\&\&\& $p<0.0001$ vs. CTL + FA cells. CTR. control cells; FA: iron/ascorbate $(200 \mu \mathrm{M} / 0.5 \mathrm{mM})$; BHT: Butylated hydroxy toluene $(0.5 \mathrm{mM})$. 


\subsection{Apolipoprotein Biogenesis}

Since Apos are important components of lipoproteins, their biogenesis was assessed following the incubation of CTL and CFTR ${ }^{-/-}$cells with $\left({ }^{35} \mathrm{~S}\right)$-methionine as a radiolabelled precursor. $\mathrm{CFTR}^{-/-}$ cells spontaneously synthetized Apo B-48 (143\%, $p<0.001)$ (Figure 8E) and Apo A-I $(151 \%, p<0.01)$ (Figure $8 \mathrm{~F}$ ) in higher quantities than CTL cells. Fe/Asc reduced the de novo synthesis of Apo B-48 without a significant effect on Apo A-I, but BHT intensified the synthesis in both cell types.

\section{Discussion}

CFTR-mediated fluid secretion is necessary for appropriate intestinal physiology [36], but CFTR mutations lead to various intestinal manifestations [37]. The most prominent disorders in the CF gastrointestinal tract include intestinal obstruction, hyperpermeability, impaired secretion of mucus and bicarbonate, bacterial overgrowth, microflora changes, hyperacidity, dysmotility, and malignancies [38]. The current data are consistent with and support the findings of our previous study demonstrating that the simple knockout of CFTR in intestinal epithelium causes redox disequilibrium [17]. However, the present innovative work was able to highlight the mitochondrial dysfunction in response to intestinal CFTR depletion, which was underlined by the derangement of FA $\beta$-oxidation, oxidative phosphorylation, and energy production, along with apoptosis amplification. These disturbances were associated with the down-regulation of PGC- $1 \alpha$, a master regulator of mitochondrial biogenesis and oxidative metabolism [39]. Concomitantly, a significant stimulation was observed in lipogenesis, lipid synthesis, apo biogenesis and lipoprotein production. Overall, these original data demonstrate that CFTR deficiency influences multiple aspects of intestinal cellular and mitochondrial homeostasis.

Most cellular studies on the role of CFTR generally employed genetic manipulations that only partially reduce cellular CFTR expression. However, heterozygotes with a single CFTR mutation do not have CF, suggesting that partial loss of CFTR function could not contribute to the disease. Thus, the ZFN technique used in the present study provides a considerable advantage since it leads to the disruption of all CFTR transcripts and to the total depletion of the CFTR protein, which mimics the homozygous CF phenotype. Moreover, the genetic engineering was carried out in Caco-2/15 cells that undergo a spontaneous differentiation leading to the formation of a monolayer of cells expressing several morphological and functional characteristics of mature human enterocytes [40]. This remarkable intestinal model is not only regarded as the most convenient for the investigation of gut absorption and interactions [29], but it has been fully appropriate in our hands to explore lipid/lipoprotein homeostasis, OxS and inflammation [40]. Therefore, we are very confident that our experimental tools are fully optimal for the scrutiny of the modulatory role of CFTR in mitochondrial function.

ROS overproduction in CF is generally attributed to malabsorption of fat-soluble antioxidant vitamins [41], infection conditions [42], stimulation of NADPH oxidases through inflammation mediators [42] and a constitutive defect of GSH metabolism [43]. However, our recent studies showed that the very fact of abrogating the CFTR gene expression in intestinal cells was sufficient to induce OxS and to increase susceptibility to pro-oxidants [17]. The results of the present work go beyond this knowledge since they underscore the impact of CFTR depletion on mitochondrial redox homeostasis [44]. A potential mechanism for the pro-oxidant action of $\mathrm{CFTR}^{-/-}$in mitochondria could be through the noted down-regulation of PGC- $1 \alpha$, a key regulator of the gene expression of antioxidant enzymes such as superoxide dismutase, glutathione peroxidase and catalase [45]. Furthermore, as PGC-1 $\alpha$ modulates the antioxidant Keap1-Nrf2-ARE pathway [8], its decreased expression noted in our experiments could have been behind the down-regulation of Nrf2, a potent stimulator of oxidant scavenging systems. Although the fall of these powerful transcription factors may explain the mitochondrial imbalance of oxidants and anti-oxidants, additional work is needed to elucidate the underlying mechanisms for the interactions between CFTR and PGC- $1 \alpha$. But at the moment, all we know is that the effects of PGC- $1 \alpha$ are likely to involve interactions with several DNA-binding transcription factors, such as CBP, the binding protein of CREB (cAMP response element binding 
protein), which brings PGC- $1 \alpha$ to the regulatory regions of target genes [46]. Given the alterations of CBP expression caused by CFTR deficiency [46,47], it is possible to suggest that PGC-1 $\alpha$ may be unable to coordinate regulation of transcription and splicing in response to signals relaying metabolic needs, thereby resulting in the dysregulation of mitochondrial biogenesis and function, as well as abnormal energy metabolism.

Nrf2 protein is considered as one of the main cellular defense mechanisms against OxS. It is central in the upregulation of endogenous antioxidant response [48]. In fact, Nrf2 activates the transcription of antioxidant enzymes by binding to the antioxidant response element (ARE) in the promoter regions of its target genes $[49,50]$. In our previous study, we demonstrated that CFTR KO resulted in significantly increased cellular malondialdehyde, a biomarker of OxS, and decreased glutathione peroxidase and catalase activities [17]. The present work evidenced an amplified OxS in mitochondria combined with reduced Nrf2 expression. A connection has been reported between CFTR and Nrf2. First, there is an antioxidant response element in the CFTR promoter, which was reported to recruit Nrf2 and various transcription factors. But, most importantly, the CF condition alters cAMP-mediated signaling and phosphorylation of CBP in response to CFTR loss [51], thereby reducing Nrf2 association, activity and expression [52,53].

As evidenced by our observations, mitochondrial DNA integrity seemed to be affected given the drop of OGG1 protein expression in CFTR ${ }^{-/-}$cells. OGG1 is the initiating enzyme of DNA base repairs. It catalyses the excision of 8-OH-deoguanosine, the common mutagenic form of oxidized guanine, from DNA. It has been demonstrated that the alteration of cellular redox leads to the inhibition of OGG1 activity [54]. Similarly, previous studies in our laboratory demonstrated the harmful effect of OxS on mitochondria DNA integrity, essentially caused by reduced OGG1 expression [7]. Therefore, the imbalance of oxidants and anti-oxidants in $\mathrm{CFTR}^{-/-}$cells could be incriminated in the abnormally low OGG1 protein expression.

We provided evidence that CFTR deletion in intestinal epithelial cells provoked mitochondrial dysfunction as highlighted by the decline of FA $\beta$-oxidation, oxidative phosphorylation and ATP-linked respiration. The reduction in these major metabolic pathways may be explained by the down-regulation of PGC- $1 \alpha$, which represents a powerful activator of mitochondrial biogenesis, oxidative metabolism and FA $\beta$-oxidation in many tissues [55]. Through its ability to coactivate numerous DNA-binding transcription factors, including nuclear respiratory factors peroxisome proliferator-activated receptor- $\alpha$, and estrogen-related receptor- $\alpha$, it induces the expression of a core genetic program needed for mitochondrial function, DNA replication, and transcription [39]. An example of the link for the regulation of the nuclear and mitochondrial genomes by PGC- $1 \alpha$ is represented by the forced expression of PGC- $1 \alpha$ that dramatically increases mitochondrial biogenesis and oxidative metabolism in certain tissues in vivo [39], whereas deletion of both PGC-1s has the opposite effect, severely limiting respiration in skeletal muscle or heart [56]. For its part, Nrf2 plays an important role in mitochondrial homeostasis $[57,58]$. Together, our data demonstrate that CFTR deletion leads to a drop of mitochondrial respiration, FA $\beta$-oxidation and energy production by mechanisms implicating PGC- $1 \alpha$ and Nrf2.

Our experiments revealed the stimulation of lipogenic enzymes, lipid synthesis and lipoprotein production in Caco-2/15 cells with CFTR deletion. Although these data were intuitively expected given the depressed mitochondrial FA $\beta$-oxidation, the mechanisms remain unclear. Nevertheless, it should be noted that, in line with the present findings, a similar stimulatory trend was reported in previous studies using infection with short hairpin RNA interference-expressing lentiviruses, which suppressed the CFTR protein expression by 50\% [29]. Importantly, phosphorylation of AMP-activated protein kinase (AMPK) may be reduced in cells with CFTR deficiency, which will lead to a decline in ATP synthesis and low ADP/ATP [59]. Such a situation would reduce phosphorylation of downstream targets of AMPK, including ACC, which would lead to increased FA synthesis. Consistent with our findings, it is reasonable to propose that intestinal malabsorption in $\mathrm{CF}$ is not due to intracellular processes governing lipid synthesis and CM production, but rather to luminal factors, including 
exocrine pancreatic insufficiency, accumulation of viscous and sticky mucus, bacterial overgrowth, ileal hypertrophy and villous atrophy, augmented intestinal permeability, reduced secretion of sodium bicarbonate, low duodenal $\mathrm{pH}$, and bile acid precipitation [16].

Our work is original because precisely very few studies have focused on inflammation, OxS, lipids/lipoprotein formation, mitochondrial function and the expression of powerful transcriptional factors regulating intracellular events in the intestine of CF patients and animal models. In line with the present study, it has recently been reported that $\Delta$ F508 mice developed intestinal inflammation through increased neutrophil and macrophage infiltration, which induced aberrant activation of NF- $к B$ in the mucosal layer of the small intestine [60]. Similarly, intestinal epithelial cells from CF patients bearing the F508del-CFTR mutation exhibited an impressive derangement of cellular proteostasis, with OxS [61]. On the other hand, regarding the formation of intestinal lipoproteins, the literature is very poor and is limited to describing the malabsorption of fats, essentially caused by digestive defects related to pancreatic lipase, bile acids and bicarbonate [62]. The impact of CFTR deficiency on intra-enterocyte processes has been very little investigated. Yet our results are in agreement with the TG concentrations and TG/HDL-C ratios above population means [63-65], a dyslipidemic phenotype representing a sign of premature atherosclerosis that was already reported in CF patients [66]. As to mitochondrial dysfunction in CF, several hypotheses were put forward before CFTR gene discovery to incriminate this organelle as an etiological factor for the CF pathology $[6,67]$. The limited studies available in the scientific literature on the role of mitochondria in CF are cited in these two reviews, which also documented a reduction in mitochondrial Complex I electron transport chain function. Moreover, characterization of mitochondrial function in airway cells homozygous for the F508del-CFTR allele revealed impairment of oxygen consumption, $\Delta \Psi$ generation, adenine nucleotide translocator-dependent ADP/ATP exchange and both mitochondrial Complex I and IV activities [68]. However, there have been no additional studies to determine the full set of mitochondrial alterations in the gut of CF patients and animal models.

While little information is available for PGC- $1 \alpha$, further observations are provided in the literature on the role of Nrf2 and lipoprotein metabolism. Mice with Nrf2 knockout exhibit high serum TG/lipids and enhanced VLDL secretion in association with induced hepatic apo B and microsomal triacylglycerol transfer lipoprotein [69]. Accordingly, Nrf2 deficiency retards atherosclerotic lesion development [70] and aggravates atherosclerosis in $\mathrm{LDLR}^{-/-}$mice [71,72]. However, controversial findings were also reported since Nrf2 deficiency alleviates atherosclerosis in hypercholesterolemic ApoE ${ }^{-/-}$mice $[73,74]$. Therefore, additional studies are warranted in order to define the contribution of Nrf2 to intestinal lipoprotein metabolism and cardiovascular diseases, especially in response to CFTR deficiency that affects the expression of Nrf2.

\section{Conclusions}

The current work provides a gathering body of evidence related to the role of CFTR in the preservation of mitochondrial dysfunction in enterocytes. Clearly, CFTR deficiency leads to dysfunction in mitochondrial energy metabolism as exemplified by the deterioration of FA $\beta$-oxidation, oxidative phosphorylation and ATP production in intestinal epithelial cells. The data also highlight the adverse effects of CFTR deletion on the expansion of cellular lipogenesis and lipoprotein output. Although the findings pointed out the implication of OxS and robust transcription factors in the disruption of cellular and mitochondrial homeostasis, further studies are needed to delineate the specific mechanisms.

Author Contributions: Conceptualization, E.L.; Methodology, E.L.; Validation, M.L.K., A.S. and C.G.; Formal Analysis, M.L.K., A.S. and E.L.; Resources, E.L.; Data Curation, M.L.K.; Writing-Original Draft Preparation, M.L.K. and E.L.; Writing-Review \& Editing, M.L.K, E.S., E.B., Y.B. and E.L.; Visualization, E.L.; Supervision, E.L.; Funding Acquisition, E.L.

Acknowledgments: The authors thank Mrs. Schohraya Spahis for her technical assistance. The current work was supported by research grants from the Canadian Cystic Fibrosis Foundation (CFC-FKC-2388; CFC-FKC-3007) and the JA DeSève Research Chair in Nutrition (E.L.). 
Conflicts of Interest: The authors declare no conflict of interest.

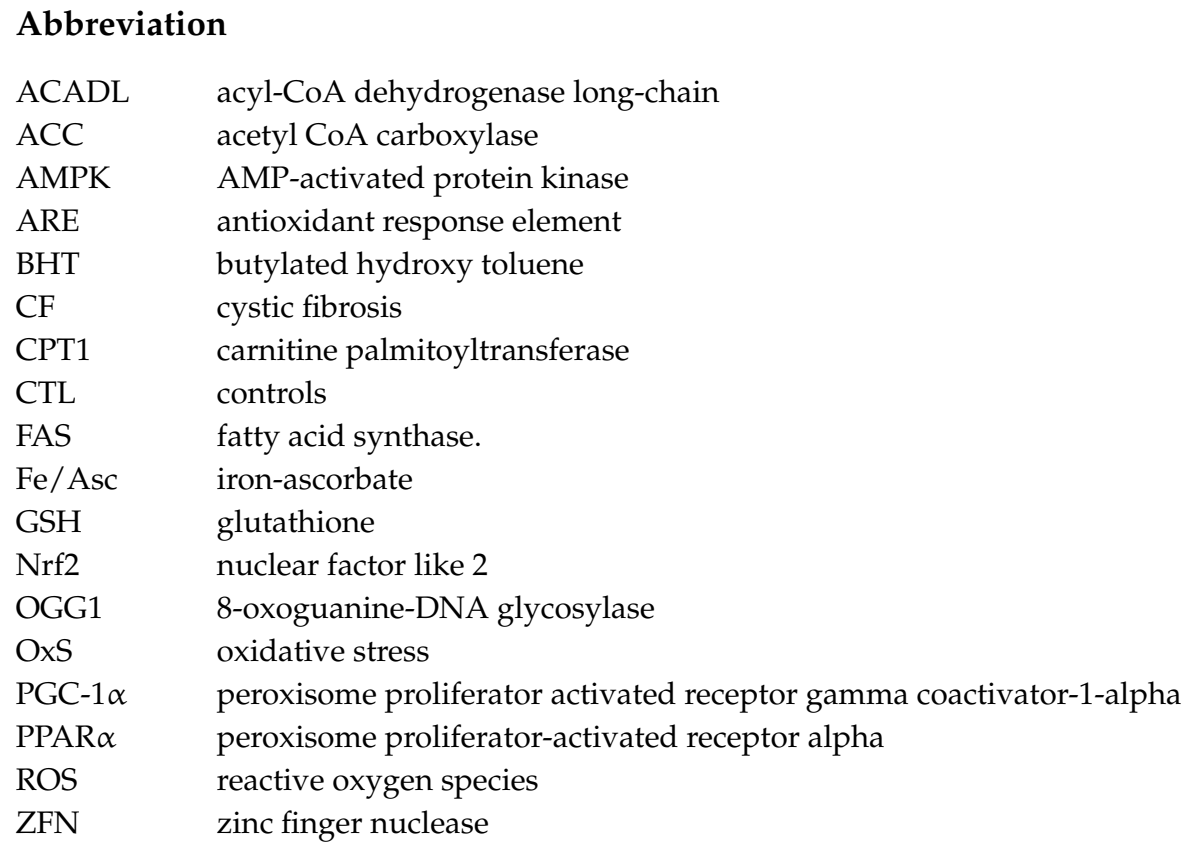

\section{References}

1. Ravilly, S.; Le Roux, E.; Bellis, G.; Dufour, F. Epidémiologie et physiopathologie de la mucoviscidose. Rev. Francoph. Lab. 2007, 397, 26-36. [CrossRef]

2. Storni, V.; Claustres, M.; Chinet, T.; Ravilly, S. Diagnostic de la mucoviscidose. Arch. Pédiatr. 2001, 8, 818-832. [CrossRef]

3. Biswas, S.; Chida, A.S.; Rahman, I. Redox modifications of protein-thiols: Emerging roles in cell signaling. Biochem. Pharmacol. 2006, 71, 551-564. [CrossRef] [PubMed]

4. Nzengue, Y. Comparaison des Mécanismes de Toxicité Redox du Cadmium, du Cuivre et du Zinc: Place des Métallothionéines et de p53. Ph.D. Thesis, Université Joseph-Fourier-Grenoble I, Joseph Fournier, Grenoble, France, 2008.

5. Galli, F.; Battistoni, A.; Gambari, R.; Pompella, A.; Bragonzi, A.; Pilolli, F.; Iuliano, L.; Piroddi, M.; Dechecchi, M.C.; Cabrini, G. Oxidative stress and antioxidant therapy in cystic fibrosis. Biochim. Biophys. Acta 2012, 1822, 690-713. [CrossRef] [PubMed]

6. Kleme, M.L.; Levy, E. Cystic fibrosis-related oxidative stress and intestinal lipid disorders. Antioxid. Redox. Signal. 2015, 22, 614-631. [CrossRef] [PubMed]

7. Taha, R.; Seidman, E.; Mailhot, G.; Boudreau, F.; Gendron, F.P.; Beaulieu, J.F.; Menard, D.; Delvin, E.; Amre, D.; Levy, E. Oxidative stress and mitochondrial functions in the intestinal Caco-2/15 cell line. PLoS ONE 2010, 5, e11817. [CrossRef] [PubMed]

8. Scarpulla, R.C.; Vega, R.B.; Kelly, D.P. Transcriptional integration of mitochondrial biogenesis. Trends Endocrinol. Metab. 2012, 23, 459-466. [CrossRef] [PubMed]

9. Garcia-Quintans, N.; Prieto, I.; Sanchez-Ramos, C.; Luque, A.; Arza, E.; Olmos, Y.; Monsalve, M. Regulation of endothelial dynamics by PGC-1alpha relies on ROS control of VEGF-A signaling. Free Radic. Biol. Med. 2016, 93, 41-51. [CrossRef] [PubMed]

10. Fujimori, N.; Oono, T.; Igarashi, H.; Ito, T.; Nakamura, T.; Uchida, M.; Coy, D.H.; Jensen, R.T.; Takayanagi, R. Vasoactive intestinal peptide reduces oxidative stress in pancreatic acinar cells through the inhibition of NADPH oxidase. Peptides 2011, 32, 2067-2076. [CrossRef] [PubMed]

11. Meyerholz, D.K.; Stoltz, D.A.; Pezzulo, A.A.; Welsh, M.J. Pathology of gastrointestinal organs in a porcine model of cystic fibrosis. Am. J. Pathol. 2010, 176, 1377-1389. [CrossRef] [PubMed]

12. Petrov, M.S. Therapeutic implications of oxidative stress in acute and chronic pancreatitis. Curr. Opin. Clin. Nutr. Metab. Care 2010, 13, 562-568. [CrossRef] [PubMed] 
13. Njoroge, S.W.; Laposata, M.; Katrangi, W.; Seegmiller, A.C. DHA and EPA reverse cystic fibrosis-related FA abnormalities by suppressing FA desaturase expression and activity. J. Lipid. Res. 2012, 53, 257-265. [CrossRef] [PubMed]

14. Strandvik, B. Fatty acid metabolism in cystic fibrosis. Prostaglandins Leukot. Essent. Fat. Acids 2010, 83, 121-129. [CrossRef] [PubMed]

15. Baldwin, A.S., Jr. Series introduction: the transcription factor NF-kappaB and human disease. J. Clin. Investig. 2001, 107, 3-6. [CrossRef] [PubMed]

16. Reis, F.J.C.; Damaceno, N. Cystic fibrosis. J. Pediatr. (Rio J.) 1998, 74 (Suppl. 1), S76-S94. [CrossRef]

17. Kleme, M.L.; Sane, A.T.; Garofalo, C.; Levy, E. Targeted CFTR gene disruption with zinc-finger nucleases in human intestinal epithelial cells induces oxidative stress and inflammation. Int. J. Biochem. Cell Biol. 2016, 74, 84-94. [CrossRef] [PubMed]

18. Morel, Y.; Barouki, R. Influence du stress oxydant sur la régulation des gènes. Rev. Méd./Sci. 1998, 14, 9. [CrossRef]

19. Mailhot, G.; Rabasa-Lhoret, R.; Moreau, A.; Berthiaume, Y.; Levy, E. CFTR depletion results in changes in fatty acid composition and promotes lipogenesis in intestinal Caco 2/15 cells. PLoS ONE 2010, 5, e10446. [CrossRef]

20. Precourt, L.P.; Marcil, V.; Ntimbane, T.; Taha, R.; Lavoie, J.C.; Delvin, E.; Seidman, E.G.; Beaulieu, J.F.; Levy, E. Antioxidative properties of paraoxonase 2 in intestinal epithelial cells. Am. J. Physiol. Gastrointest. Liver Physiol. 2012, 303, G623-G634. [CrossRef] [PubMed]

21. Escaffit, F.; Pare, F.; Gauthier, R.; Rivard, N.; Boudreau, F.; Beaulieu, J.F. Cdx2 modulates proliferation in normal human intestinal epithelial crypt cells. Biochem. Biophys. Res. Commun. 2006, 342, 66-72. [CrossRef] [PubMed]

22. Leahy, J.; Spahis, S.; Bonneil, E.; Garofalo, C.; Grimard, G.; Morel, S.; Laverdiere, C.; Krajinovic, M.; Drouin, S.; Delvin, E.; et al. Insight from mitochondrial functions and proteomics to understand cardiometabolic disorders in survivors of acute lymphoblastic leukemia. Metabolism 2018, 85, 151-160. [CrossRef] [PubMed]

23. Yeganeh, P.R.; Leahy, J.; Spahis, S.; Patey, N.; Desjardins, Y.; Roy, D.; Delvin, E.; Garofalo, C.; Leduc-Gaudet, J.P.; St-Pierre, D.; et al. Apple peel polyphenols reduce mitochondrial dysfunction in mice with DSS-induced ulcerative colitis. J. Nutr. Biochem. 2018, 57, 56-66. [CrossRef] [PubMed]

24. Denis, M.C.; Roy, D.; Yeganeh, P.R.; Desjardins, Y.; Varin, T.; Haddad, N.; Amre, D.; Sane, A.T.; Garofalo, C.; Furtos, A.; et al. Apple peel polyphenols: a key player in the prevention and treatment of experimental inflammatory bowel disease. Clin. Sci. (London) 2016, 130, 2217-2237. [CrossRef] [PubMed]

25. Montoudis, A.; Seidman, E.; Boudreau, F.; Beaulieu, J.F.; Menard, D.; Elchebly, M.; Mailhot, G.; Sane, A.T.; Lambert, M.; Delvin, E.; et al. Intestinal fatty acid binding protein regulates mitochondrion beta-oxidation and cholesterol uptake. J. Lipid. Res. 2008, 49, 961-972. [CrossRef] [PubMed]

26. Mehran, M.; Levy, E.; Bendayan, M.; Seidman, E. Lipid, apolipoprotein, and lipoprotein synthesis and secretion during cellular differentiation in Caco-2 cells. Vitro Cell. Dev. Biol. Anim. 1997, 33, 118-128. [CrossRef]

27. Levy, E.; Garofalo, C.; Thibault, L.; Dionne, S.; Daoust, L.; Lepage, G.; Roy, C.C. Intraluminal and intracellular phases of fat absorption are impaired in essential fatty acid deficiency. Am. Physi. Soc. 1992, 262, G319-G326. [CrossRef] [PubMed]

28. Levy, E.; Sinnett, D.; Thibault, L.; Nguyen, T.D.; Delvin, E.; Menard, D. Insulin modulation of newly synthesized apolipoproteins B-100 and B-48 in human fetal intestine: gene expression and mRNA editing are not involved. FEBS Lett. 1996, 393, 253-258. [CrossRef]

29. Mailhot, G.; Ravid, Z.; Barchi, S.; Moreau, A.; Rabasa-Lhoret, R.; Levy, E. CFTR knockdown stimulates lipid synthesis and transport in intestinal Caco-2/15 cells. Am. J. Physiol. Gastrointest. Liver Physiol. 2009, 297, G1239-G1249. [CrossRef] [PubMed]

30. Levy, E.; Ben Djoudi Ouadda, A.; Spahis, S.; Sane, A.T.; Garofalo, C.; Grenier, E.; Emonnot, L.; Yara, S.; Couture, P.; Beaulieu, J.F.; et al. PCSK9 plays a significant role in cholesterol homeostasis and lipid transport in intestinal epithelial cells. Atherosclerosis 2013, 227, 297-306. [CrossRef] [PubMed]

31. Morel, S.; Leahy, J.; Fournier, M.; Lamarche, B.; Garofalo, C.; Grimard, G.; Poulain, F.; Delvin, E.; Laverdiere, C.; Krajinovic, M.; et al. Lipid and lipoprotein abnormalities in acute lymphoblastic leukemia survivors. J. Lipid. Res. 2017, 58, 982-993. [CrossRef] [PubMed] 
32. Sane, A.T.; Seidman, E.; Peretti, N.; Kleme, M.L.; Delvin, E.; Deslandres, C.; Garofalo, C.; Spahis, S.; Levy, E. Understanding Chylomicron Retention Disease Through Sar1b Gtpase Gene Disruption: Insight From Cell Culture. Arterioscler. Thromb. Vasc. Biol. 2017, 37, 2243-2251. [CrossRef] [PubMed]

33. Levy, E.; Garofalo, C.; Rouleau, T.; Gavino, V.; Bendayan, M. Impact of essential fatty acid deficiency on hepatic sterol metabolism in rats. Hepatology 1996, 23, 848-857. [CrossRef] [PubMed]

34. Bhakat, K.K.; Mokkapati, S.K.; Boldogh, I.; Hazra, T.K.; Mitra, S. Acetylation of human 8-oxoguanine-DNA glycosylase by p300 and its role in 8-oxoguanine repair in vivo. Mol. Cell. Biol. 2006, 26, 1654-1665. [CrossRef] [PubMed]

35. Kukidome, D.; Nishikawa, T.; Sonoda, K.; Imoto, K.; Fujisawa, K.; Yano, M.; Motoshima, H.; Taguchi, T.; Matsumura, T.; Araki, E. Activation of AMP-activated protein kinase reduces hyperglycemia-induced mitochondrial reactive oxygen species production and promotes mitochondrial biogenesis in human umbilical vein endothelial cells. Diabetes 2006, 55, 120-127. [CrossRef] [PubMed]

36. Rowe, S.M.; Miller, S.; Sorscher, E.J. Cystic Fibrosis. N. Engl. J. Med. 2005, 352, 10. [CrossRef] [PubMed]

37. Sabharwal, S. Gastrointestinal Manifestations of Cystic Fibrosis. Gastroenterol. Hepatol. (NY) 2016, 12, $43-47$.

38. De Lisle, R.C.; Borowitz, D. The cystic fibrosis intestine. Cold Spring Harb. Perspect Med. 2013, 3, a009753. [CrossRef] [PubMed]

39. Handschin, C.; Spiegelman, B.M. Peroxisome proliferator-activated receptor gamma coactivator 1 coactivators, energy homeostasis, and metabolism. Endocr. Rev. 2006, 27, 728-735. [CrossRef] [PubMed]

40. Courtois, F.; Seidman, G.E.; Delvin, E.; Asselin, C.; Bernotti, S.; Ledoux, M.; Levy, E. Membrane peroxidation by lipopolysaccharide and iron-ascorbate adversely affects Caco-2 cell function: Beneficial role of butyric acid. Am. J. Clin. Nutr. 2003, 77, 744-750. [CrossRef] [PubMed]

41. Oudshoorn, J.H.; Lecluse, A.L.Y.; Berg, R.v.d.; Wouter, H.J.V.; Laag, J.v.d.; Houwen, R.H.J. Decreased Coenzyme Q10 Concentration in Plasma of Children with Cystic Fibrosis. J. Ped. Gastroenterol. Nutr. 2006, 43, 646-650. [CrossRef]

42. Day, B.J.; van Heeckeren, A.M.; Min, E.; Velsor, L.W. Role for Cystic Fibrosis Transmembrane Conductance Regulator Protein in a Glutathione Response to Bronchopulmonary Pseudomonas Infection. Infect. Immun. 2004, 72, 2045-2051. [CrossRef] [PubMed]

43. Naruse, S. cystic fibrosis and related diseases of the pancreas. Best Pract. Res. Clin. Gastroenterol. 2002, 163, 511-526. [CrossRef] [PubMed]

44. Cadenas, E.; Davies, K.J. Mitochondrial free radical generation, oxidative stress, and aging. Free Radic. Biol. Med. 2000, 29, 222-230. [CrossRef]

45. St-Pierre, J.; Drori, S.; Uldry, M.; Silvaggi, J.M.; Rhee, J.; Jager, S.; Handschin, C.; Zheng, K.; Lin, J.; Yang, W.; et al. Suppression of reactive oxygen species and neurodegeneration by the PGC-1 transcriptional coactivators. Cell 2006, 127, 397-408. [CrossRef] [PubMed]

46. Knutti, D.; Kralli, A. PGC-1, a versatile coactivator. Trends Endocrinol. Metab. 2001, 12, 360-365. [CrossRef]

47. Ichida, M.; Nemoto, S.; Finkel, T. Identification of a specific molecular repressor of the peroxisome proliferator-activated receptor gamma Coactivator-1 alpha (PGC-1alpha). J. Biol. Chem. 2002, 277, 50991-50995. [CrossRef] [PubMed]

48. Kensler, T.W.; Wakabayashi, N.; Biswal, S. Cell survival responses to environmental stresses via the Keap1-Nrf2-ARE pathway. Annu. Rev. Pharmacol. Toxicol. 2007, 47, 89-116. [CrossRef] [PubMed]

49. Rushmore, T.H.; Morton, M.R.; Pickett, C.B. The antioxidant responsive element. Activation by oxidative stress and identification of the DNA consensus sequence required for functional activity. J. Biol. Chem. 1991, 266, 11632-11639. [PubMed]

50. Zhang, D.D. Mechanistic studies of the Nrf2-Keap1 signaling pathway. Drug. Metab. Rev. 2006, 38, 769-789. [CrossRef] [PubMed]

51. Manson, M.E.; Corey, D.A.; White, N.M.; Kelley, T.J. cAMP-mediated regulation of cholesterol accumulation in cystic fibrosis and Niemann-Pick type C cells. Am. J. Physiol. Lung. Cell. Mol. Physiol. 2008, 295, L809-L819. [CrossRef] [PubMed]

52. Ziady, A.G.; Sokolow, A.; Shank, S.; Corey, D.; Myers, R.; Plafker, S.; Kelley, T.J. Interaction with CREB binding protein modulates the activities of Nrf2 and NF-kappaB in cystic fibrosis airway epithelial cells. Am. J. Physiol. Lung. Cell. Mol. Physiol. 2012, 302, L1221-L1231. [CrossRef] [PubMed] 
53. Katoh, Y.; Itoh, K.; Yoshida, E.; Miyagishi, M.; Fukamizu, A.; Yamamoto, M. Two domains of Nrf2 cooperatively bind CBP, a CREB binding protein, and synergistically activate transcription. Genes Cells 2001, 6, 857-868. [CrossRef] [PubMed]

54. Bravard, A.; Vacher, M.; Gouget, B.; Coutant, A.; de Boisferon, F.H.; Marsin, S.; Chevillard, S.; Radicella, J.P. Redox regulation of human OGG1 activity in response to cellular oxidative stress. Mol. Cell. Biol. 2006, 26, 7430-7436. [CrossRef] [PubMed]

55. Finck, B.N.; Kelly, D.P. PGC-1 coactivators: inducible regulators of energy metabolism in health and disease. J. Clin. Investig. 2006, 116, 615-622. [CrossRef] [PubMed]

56. Zechner, C.; Lai, L.; Zechner, J.F.; Geng, T.; Yan, Z.; Rumsey, J.W.; Collia, D.; Chen, Z.; Wozniak, D.F.; Leone, T.C.; et al. Total skeletal muscle PGC-1 deficiency uncouples mitochondrial derangements from fiber type determination and insulin sensitivity. Cell Metab. 2010, 12, 633-642. [CrossRef] [PubMed]

57. Dinkova-Kostova, A.T.; Abramov, A.Y. The emerging role of Nrf2 in mitochondrial function. Free Radic. Biol. Med. 2015, 88, 179-188. [CrossRef] [PubMed]

58. Cheng, X.; Siow, R.C.; Mann, G.E. Impaired redox signaling and antioxidant gene expression in endothelial cells in diabetes: A role for mitochondria and the nuclear factor-E2-related factor 2-Kelch-like ECH-associated protein 1 defense pathway. Antioxid. Redox. Signal. 2011, 14, 469-487. [CrossRef] [PubMed]

59. Harmel, E.; Grenier, E.; Bendjoudi Ouadda, A.; El Chebly, M.; Ziv, E.; Beaulieu, J.F.; Sane, A.; Spahis, S.; Laville, M.; Levy, E. AMPK in the small intestine in normal and pathophysiological conditions. Endocrinology 2014, 155, 873-888. [CrossRef] [PubMed]

60. Liu, K.; Zhang, X.; Zhang, J.T.; Tsang, L.L.; Jiang, X.; Chan, H.C. Defective CFTR- $\beta$-catenin interaction promotes NF-KB nuclear translocation and intestinal inflammation in cystic fibrosis. Oncotarget 2016, 7, 64030-64042. [PubMed]

61. Esposito, S.; Tosco, A.; Villella, V.R.; Raia, V.; Kroemer, G.; Maiuri, L. Manipulating proteostasis to repair the F508del-CFTR defect in cystic fibrosis. Mol. Cell. Pediatr. 2016, 3, 13. [CrossRef] [PubMed]

62. Peretti, N.; Marcil, V.; Drouin, E.; Levy, E. Mechanisms of lipid malabsorption in Cystic Fibrosis: The impact of essential fatty acids deficiency. Nutr. Metab. (London) 2005, 2, 18. [CrossRef] [PubMed]

63. Ishimo, M.C.; Belson, L.; Ziai, S.; Levy, E.; Berthiaume, Y.; Coderre, L.; Rabasa-Lhoret, R. Hypertriglyceridemia is associated with insulin levels in adult cystic fibrosis patients. J. Cyst. Fibros. 2013, 12, 271-276. [CrossRef] [PubMed]

64. Levy, E.; Lepage, G.; Bendayan, M.; Ronco, N.; Thibault, L.; Galeano, N.; Smith, L.; Roy, C.C. Relationship of decreased hepatic lipase activity and lipoprotein abnormalities to essential fatty acid deficiency in cystic fibrosis patients. J. Lipid. Res. 1989, 30, 1197-1209. [PubMed]

65. Woestenenk, J.W.; Schulkes, D.A.; Schipper, H.S.; van der Ent, C.K.; Houwen, R.H.J. Dietary intake and lipid profile in children and adolescents with cystic fibrosis. J. Cyst. Fibros 2017, 16, 410-417. [CrossRef] [PubMed]

66. Buehler, T.; Steinmann, M.; Singer, F.; Regamey, N.; Casaulta, C.; Schoeni, M.H.; Simonetti, G.D. Increased arterial stiffness in children with cystic fibrosis. Eur. Respir. J. 2012, 39, 1536-1537. [CrossRef] [PubMed]

67. Valdivieso, A.G.; Santa-Coloma, T.A. CFTR activity and mitochondrial function. Redox. Biol. 2013, 1, $190-202$. [CrossRef] [PubMed]

68. Atlante, A.; Favia, M.; Bobba, A.; Guerra, L.; Casavola, V.; Reshkin, S.J. Characterization of mitochondrial function in cells with impaired cystic fibrosis transmembrane conductance regulator (CFTR) function. J. Bioenerg. Biomembr. 2016, 48, 197-210. [CrossRef] [PubMed]

69. Xu, J.; Donepudi, A.C.; More, V.R.; Kulkarni, S.R.; Li, L.; Guo, L.; Yan, B.; Chatterjee, T.; Weintraub, N.; Slitt, A.L. Deficiency in Nrf2 transcription factor decreases adipose tissue mass and hepatic lipid accumulation in leptin-deficient mice. Obesity (Silver Spring) 2015, 23, 335-344. [CrossRef] [PubMed]

70. Ruotsalainen, A.K.; Lappalainen, J.P.; Heiskanen, E.; Merentie, M.; Sihvola, V.; Napankangas, J.; Lottonen-Raikaslehto, L.; Kansanen, E.; Adinolfi, S.; Kaarniranta, K.; et al. Nrf2 deficiency impairs atherosclerotic lesion development but promotes features of plaque instability in hypercholesterolemic mice. Cardiovasc Res. 2018. [CrossRef] [PubMed]

71. Collins, A.R.; Gupte, A.A.; Ji, R.; Ramirez, M.R.; Minze, L.J.; Liu, J.Z.; Arredondo, M.; Ren, Y.; Deng, T.; Wang, J.; et al. Myeloid deletion of nuclear factor erythroid 2-related factor 2 increases atherosclerosis and liver injury. Arterioscler. Thromb. Vasc. Biol. 2012, 32, 2839-2846. [CrossRef] [PubMed] 
72. Ruotsalainen, A.K.; Inkala, M.; Partanen, M.E.; Lappalainen, J.P.; Kansanen, E.; Makinen, P.I.; Heinonen, S.E.; Laitinen, H.M.; Heikkila, J.; Vatanen, T.; et al. The absence of macrophage Nrf2 promotes early atherogenesis. Cardiovasc. Res. 2013, 98, 107-115. [CrossRef] [PubMed]

73. Harada, N.; Ito, K.; Hosoya, T.; Mimura, J.; Maruyama, A.; Noguchi, N.; Yagami, K.; Morito, N.; Takahashi, S.; Maher, J.M.; et al. Nrf2 in bone marrow-derived cells positively contributes to the advanced stage of atherosclerotic plaque formation. Free Radic. Biol. Med. 2012, 53, 2256-2262. [CrossRef] [PubMed]

74. Sussan, T.E.; Jun, J.; Thimmulappa, R.; Bedja, D.; Antero, M.; Gabrielson, K.L.; Polotsky, V.Y.; Biswal, S. Disruption of Nrf2, a key inducer of antioxidant defenses, attenuates ApoE-mediated atherosclerosis in mice. PLOS ONE 2008, 3, e3791. [CrossRef] [PubMed]

(C) 2018 by the authors. Licensee MDPI, Basel, Switzerland. This article is an open access article distributed under the terms and conditions of the Creative Commons Attribution (CC BY) license (http:/ / creativecommons.org/licenses/by/4.0/). 